\title{
Paintings of Metal Artifacts according to the Arabic School in Iraq and Syria
}

\author{
Smah Abdel Rahman Mahmoud ${ }^{\mathrm{a}}$ \\ , Essam Adel Morsi ${ }^{\mathrm{b}}$, \\ Shaaban Samir Abdel Razek ${ }^{\mathrm{c}}$, \\ , Enas Mustafa Abdel Gaber ${ }^{\mathrm{d}}$ \\ ${ }^{a}$ Professor of Tourism Guidance-Faculty of Tourism and Hotels-Minia University \\ ${ }^{b}$ Professor of Islamic Archaeology- Archaeology Department - faculty of Arts - Minia University \\ ${ }^{c}$ Associate Professor of Tourism Guidance-Faculty of Tourism and Hotels-Minia University \\ ${ }^{d}$ Tourism Guidance Department-Minia University
}

\section{Keywords}

Painting

Decoration

Applied

Miniature

Artist

\begin{abstract}
Most of the Islamic arts rely on painting to decorate their products such as applied artifacts from metal, textile, ceramics, glass, and wood, etc. which makes them appear in a magnificent art form. The miniatures that decorated the pages of the manuscripts, or their text, have become a source for the study of applied artifacts as ewers, basins, Chandeliers, Candlestick, Incense burners, and forms of ornaments. Through the miniatures of the manuscripts, scholars have been able to learn the applied forms of artifacts in all areas of Islamic art. And the study here focuses on metal artifacts, comparing them to those on display in museums.
\end{abstract}




\section{Research importance:}

The importance of studying the paintings of metal artifacts through the miniatures of the manuscripts to give a valuable and essential overview of the social, economic, and cultural life through the miniatures of the manuscripts of the Arabic school, it is beneficial in revealing the state of society, the style of life and identifying the layers of society and their material and technical level, identifying the artistic methods that appeared and spread in paintings and decorations, seeking aspects of innovation and creativity, knowing the artistic and industrial influence and illustrating new styles of different metal artifacts.

\section{Research objective:}

To shed light on metal artifacts in the Arabic School to elucidate the similarities and differences between the forms of metal artifacts in the miniatures of the manuscripts of the Arab school and those preserved in different museums. Demonstrate the artist's ability to show some aspects of daily life through the miniatures of the Arab School.

\section{Introduction}

Metal artifacts have played a great role in the lives of Muslims throughout the ages, and where they cannot be viewed as mere tools for decoration or fulfilling some practical functions, but in fact they appear as a cultural and artistic reflection that highlights the artist's knowledge of the Muslim manufacturer of metals and how to form and formulate them in different decorative artistic methods It also played an important role in the lives of the members of the Islamic community socially, culturally and politically, and it has achieved success in this to the extent that metal artifacts have a market to which nations, whether within the Muslim world or European countries, are eager through trade, crusades, etc.

Although most of these masterpieces were specially made to meet the desires of the sultans and princes, they truly reflect the innovative capabilities of the Muslim artist, and he exerted in them the utmost of his thought, creation and creativity, which was helped by the encouragement of rulers and their patronage of arts in general and metal artifacts in particular ${ }^{(1)}$.

As a result of the great development in the manufacture and decoration of metal artifacts in all its forms, this has had a clear impact on the interest of the Muslim painter in painting many of its forms in the paintings of manuscripts, as will be seen from the study review of the forms of metal artifacts that appeared in the miniatures of manuscripts.

The school in Painting generally means agreement in features and style, and it is possible that the artistic school will not end with the end of the political period to 
which it is attributed, and also it is not necessary for a particular school to be established after the interruption of another school, but it is possible for the two different schools to live simultaneously, such as the school The Mamluk and the Mughal school in Iran, according to the difference in style between them ${ }^{(1)}$. It is found miniatures that represent a particular school while it dates back to different eras, such as the Arab school in Baghdad before the Mongols took over it, and in the Mamluk state in Egypt and Syria in the eighth century A.H.

Prof. Dr. Hassan Al-Pasha mentioned that the name of the Arab school was named according to the style of paintings in Arabic manuscripts, the oldest of which dates back to the 4th century A.H. / 10th century A.D. This school is considered the oldest among the Islamic painting schools known in the manuscripts and has spread in most of the Islamic world in the 7th -9 th century A.H. / 13th $-15^{\text {th }}$ century A.D.

\section{Descriptive study:}

\begin{tabular}{|l|l|}
\hline Plate No. & $(1)$ \\
\hline Name of Manuscript & The Four Blessings \\
\hline Language of Manuscript & Arabic \\
\hline Production Place & Egypt \\
\hline Production Date & $21180 /-\$ 576$ \\
\hline Conservation Place & Bibliothèque Nationale de France \\
\hline Inventory Number & 13 Coptic \\
\hline
\end{tabular}

\section{References:}

Abo Al-Hamad Mahmoud Farghali, The Islamic painting originated and the attitude of Islam towards it. Fig.23 page: 415.

أبو الحمد محمود فرغلي، التصوبير الإسلامي نثأته وموقف الإسلام منه لوحة 23،صد415 Description:

This painting represents crowds of Jews gathered for asking their ruler, Pilate, to put Jesus on trial, the artist could express some shapes of ewers, which is an ewer with a blown and conical body. A small, funnel-shaped base is attached to the body. The ewer has a small neck that ends with a circular spout. The ewer has handheld by the person who pours water from the ewer at the far left of the painting. It emerges from the body of the ewer, where the spout comes out in a curved manner. Moreover, the

د.حسن الباشاء/التصوير الإسلامى فى العصور الوسطى،1959،مكتبة نهضة مصر،/القاهرة،ـ124.1 
size of the faucet is quite wide, compared to the many forms of metal ewers on manuscript paintings.

\begin{tabular}{|l|l|}
\hline Plate No. & $(2)$ \\
\hline Describing the miniature & $\begin{array}{l}\text { The miniature represents a sitting king on } \\
\text { a high throne and in front of him his wife } \\
\text { Irakht on the left side }\end{array}$ \\
\hline Name of Manuscript & Kalila and Dimna \\
\hline Language of Manuscript & Arabic \\
\hline Miniaturist & Ibn al-Muqaffa \\
\hline Production Place & Syria \\
\hline Production Date & 1200 - 1220 A.D. / 597 - 617 A.H. \\
\hline Historical Period & Abbasid Period \\
\hline Conservation Place & Bibliothèque Nationale de France \\
\hline Inventory Number & Ms. Arabe 3465 \\
\hline
\end{tabular}

\section{References:}

-أبو الحمد محمد محد، تصاوير المخطوطات في عصر الأيوبيين دراسة آثرية فنية، صـ107،108

- Abu al-Hamad Mahmoud Muhammad, Illustrations of Manuscripts in the Age of the Ayyubids, an Artistic Archaeological Study, pp. 107-108.

\section{Description:}

The miniature represents King Plath and his wife Irakht ${ }^{(1)}$ In it,the king sits looking at his wife and crowning his head with the triangular crown, and the wife stands in a light curvature, and it is notable are interested in the painting to the metal ewer located in a hall next to the throne choir, which is a pitcher with a spherical body and has a triangular base and connects to the body a long neck that ends with a circular nozzle from which a group of flowers comes out and the ewer has a hand connected to the body and neck, but the tap comes out of the body to the top curve, shape, and through the painting, it can be said that the artist drew the ewer in this way to express two masterpieces at the same time, a ewer and a vase, where the artist drew a group of flowers and rosettes that emerge from the ewer's mouth, so the drawing of the masterpiece is in this way It has damaged its essence in terms of form and function, as 
we have not received a masterpiece in this way, used as a ewer and a vase at the same time, and from here it can be said that the artist did not succeed in drawing the masterpiece in this way, because the shape of the vase differs somewhat from the shape of the ewer, and there are many vases that were painted in miniatures of manuscripts of Arabic school, which appeared prominently showing their usual shape, and the vases kept by many foreign and Egyptian museums have their distinctive shape which is in doubt is that this masterpiece is a form of metal ewer that confirms the general composition of the masterpiece in terms of its inclusion of all the parts that make up the ewer, namely the body, the base, the neck, the hand and the tap, while the vases do not include many of these parts and the study will include the study of a collection of vases that appeared in the paintings of the Arabic school manuscripts and compare it. Similar to the metal vases held by museums in order to clarify the difference between the shape of the ewer and the shape of the vase.

\begin{tabular}{|c|c|}
\hline Plate No. & (3) \\
\hline Miniature Name & $\begin{array}{l}\text { A miniature representing the maid's } \\
\text { basin }\end{array}$ \\
\hline Name of Manuscript & $\begin{array}{l}\text { the Book combining the theory and } \\
\text { practice useful in the craft of ingenious } \\
\text { Contrivances or Kitab al-jami bayn al- } \\
\text { ilm wa lamal al-nafi fi sina'at al-hiyal }\end{array}$ \\
\hline Language of Manuscript & Arabic \\
\hline Production Date & 715 A.H./1315 A.D. \\
\hline Miniaturist & Badi al-Zaman ibn al-Razzaz al-Jazari. \\
\hline Conservation Place & Freer Museum of Art \\
\hline Inventory Number & 75030 \\
\hline
\end{tabular}

\section{References:}

Atil (E.), Renaissance of Islam (Art of the Mamluk), Washington, 1981, pl.2, p.224.

\section{Description:}

The artist drew a shape for ewer of a quite large and short one. The nozzle is the same size, although the neck is short. The difference here is in the shape of the faucet that the artist drew. It comes out of the body and bends down and ends with the nozzle, which is in the form of the head of a mythical animal resembling a dragon. It is noted that the water flows from the faucet nozzle, and perhaps the head of the faucet nozzle 
in this way suggests the extent of Chinese influences that appeared in this form. Drawing mythical animals, especially the dragon, is one of the characteristics of Chinese art, and the Muslim artist derived it in many of his works. The artistry is not only in manuscript illustrations, but in many of its decorative elements on all his productions from other materials.

\begin{tabular}{|l|l|}
\hline Plate No. & $(4)$ \\
\hline Miniature Name & $\begin{array}{l}\text { A miniature representing a mechanical } \\
\text { trick }\end{array}$ \\
\hline Name of Manuscript & $\begin{array}{l}\text { The Book combining the theory and } \\
\text { practice useful in the craft of ingenious } \\
\text { Contrivances or Kitab al-jami bayn al- } \\
\text { ilm wa lamal al-nafi fi sina'at al-hiyal }\end{array}$ \\
\hline Language of Manuscript & Arabic \\
\hline Production Date & 715 A.H./1315 A.D. \\
\hline Conservation Place & Freer Museum of Art \\
\hline
\end{tabular}

\section{References:}

Hattstein (M.) and Delius (P.), Islam (Art and Architecture), 2000, P., 195.

\section{Description:}

The artist painted the shape of the ewer different from the previous form as it differs from the usual models, so we see him drawing the ewer with its ordinary parts, the body is blown and the base It is small when compared to the base of the previous pitcher and the neck is also long and ends with a crater with a semi-spherical cover topped with a bird shape, while the tap is similar to the faucet of the previous ewer in that it comes out of the body and bends down and also ends with a nozzle on the the shape of an animal's head is unclear. 


\begin{tabular}{|l|l|}
\hline Plate No. & $(5)$ \\
\hline Object Name & Ewer of Marwan Ibn Mohammad \\
\hline Production Place & AL-Fayoum Egypt \\
\hline Materials & Brass \\
\hline Century & 1 A.H./7 A.D. \\
\hline Conservation Town & Cairo \\
\hline Conservation Place & Museum of Islamic Art \\
\hline Inventory Number & \\
\hline Dimensions & 9281 \\
\hline
\end{tabular}

\section{References:}

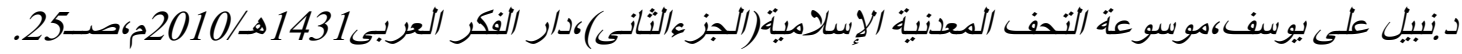
Dr. Nabil Ali Youssef, Encyclopedia of Islamic Metal Artifacts (Part Two), House of Arab Thought 1431 AH /2010 AD, p. 25.

\section{Description:}

This ewer is a great example of metal artifacts It is made of bronze and was found in the village of Abu Sir al-Malaq in Fayoum province in the ruins of a cemetery that is said to be the tomb of Marwan ibn Muhammad, the last Umayyad caliph. has the form of an inflated globular shaft with a base at its lower part. The body is decorated with several animals in different positions. Some are standing alone surrounded by floral ornaments and some others are confronted or circulating around each other. The artist skillfully expressed the crowing rooster ruffling its feathers, raising its tail and stretching its neck. Therefore, it is not surprising that we find this type of ewers in the manuscript illustrations. 


\begin{tabular}{|l|l|}
\hline Plate No. & $(6)$ \\
\hline Miniature Name & Abu Zayd sits in a drink session \\
\hline Name of Manuscript & Maqamat of Al-Hariri \\
\hline Language of Manuscript & Arabic \\
\hline Miniature (Painter) & Yahya ibn Mahmud al-Wasiti \\
\hline Production Place & Baghdad, Iraq \\
\hline Production Date & $\begin{array}{l}\text { A May 1237 A.D. / 6 Ramadan 634 } \\
\text { A.H.. }\end{array}$ \\
\hline Historical Period & Abbasid Period \\
\hline Conservation Place & Bibliothèque Nationale de France \\
\hline Inventory Number & MS. arabe 5847 (Schefer Hariri) \\
\hline
\end{tabular}

\section{References:}

- The Manuscript of Maqamat of Al-Hariri in Bibliothèque Nationale de France, Paris. Arabe. 5847.

\section{http://gallica.bnf.fr/ark:/12148/btv1b8422965p}

\section{Description:}

The painting represents Abu Zayed and Al Harith in a drink session, the clothes of the left person are decorated with geometric ornaments, and the most important thing in this painting is the shape of the ewer that is located in front of both people. The ewers are decorated with geometrical decorations.

\begin{tabular}{|l|l|}
\hline Plate No. & $(7)$ \\
\hline Miniature Name & $\begin{array}{l}\text { A miniature represents a young girl as a } \\
\text { servant bringing food to Abu Zayd and } \\
\text { al-Harith }\end{array}$ \\
\hline Name of Manuscript & Maqamat of Al-Hariri \\
\hline Language of Manuscript & Arabic \\
\hline Miniature & Umar ibn Ali ibn al-Mubarak alMawsili \\
\hline Production Place & Mosul, Iraq \\
\hline
\end{tabular}




\begin{tabular}{|l|l|}
\hline Production Date & 1256 A.D. / 654 A.H. \\
\hline Historical Period & Mamluk Perio \\
\hline Conservation Place & British Library \\
\hline Inventory Number & Ms. Or. 1200 \\
\hline
\end{tabular}

Reference: Grabar (O.), The Illustrations of the Maqamat, Chicago, University of Chicago Press, 1984 pp. 13, 52, 53, 54.

\section{Description:}

This miniature is painted inside a house with an arched frame where it belongs to a known man called the Shaykh. On the right side, we can see, the Shaykh sitting on the ground in the position of cross-legged for having the food with Abu Zayd. He is shown wearing a white headdress on his head and a green long and wide garment on his body. The Shaykh is represented with two eyebrows, two black eyes, a mustache and long black beard. He is depicted pointing to Abu Zayd to have food with him. His head is shown surrounding by a circle halo around it. A young girl standing in the middle of the painting holds a ewer in its form that corresponds to the previous ewers consisting of a blown body, a long neck and a small base.

\begin{tabular}{|l|l|}
\hline Plate No. & $(8)$ \\
\hline Miniature Name & A woman helps a pharmacist \\
\hline Name of Manuscript & Dioscorides's Materia Medica \\
\hline Language of Manuscript & Arabic \\
\hline Miniature & Abdallah ibn al-Fadl \\
\hline Production Place & Baghdad, Iraq \\
\hline Production Date & $\begin{array}{l}\text { July/August 1224 A.D. / Rajab 621 } \\
\text { A.H.. }\end{array}$ \\
\hline Historical Period & Abbasid Period \\
\hline Conservation Place & Aya Sofya, later Top Kapi Seray library \\
\hline Inventory Number & 3703,2147 \\
\hline
\end{tabular}

\section{References:}

- Florence (E. D.), Mesopotamian Manuscripts of Dioscorides, The Metropolitan Museum of Art Bulletin, New Series, Vol. 8, No. 9 (May, 1950), pp. 274-280 
- Halil (T.), Dioscorides' Materia Medica Manuscripts in Turkey, No date, p. 1.

\section{Description:}

This miniature shows a recipe for a wine for catarrhs and other ailments by two doctors: a man and a woman preparing medicine. On the right side, we can see a human figure, known as a pharmacist. He is shown in the position of preparation of medicine. The pharmacist is painted wearing a short dress and below it trouser. He is illustrated with a black beard and a turban on his head which is surrounded by a circle halo around it. While on the left side, there is a standing woman for helping the pharmacist. She is represented wearing a long robe tight dress, the artist painted a large size of basin that may be used to prepare the medicine.

\begin{tabular}{|c|c|}
\hline Plate No. & (9) \\
\hline Name of Manuscript & Maqamat of Al-Hariri \\
\hline Language of Manuscript & Arabic \\
\hline Miniature (Painter) & Yahya ibn Mahmud al-Wasiti \\
\hline Production Place & Baghdad, Iraq \\
\hline Production Date & $\begin{array}{l}3 \text { May } 1237 \text { A.D. / } 6 \text { Ramadan } 634 \\
\text { A.H.. }\end{array}$ \\
\hline Historical Period & Abbasid Period \\
\hline Conservation Place & Bibliothèque Nationale de France \\
\hline Inventory Number & MS. arabe 5847 (Schefer Hariri) \\
\hline
\end{tabular}

\section{Description:}

This miniature shows a group of people in the slave market. The story of this Maqamah tells us that al-Harith, son of Hammam after his slave dies, he goes to look for a new one. In the lower part and on the right side, we can see al-Harith standing and wearing his wide clothes. He is represented with a turban on his head and a black beard Beside al-Harith standing a man doing grape splurcation in a large basin. 


\begin{tabular}{|l|l|}
\hline Plate No. & $(10)$ \\
\hline Miniature Name & $\begin{array}{l}\text { A woman sits in front of a spinning } \\
\text { wheel }\end{array}$ \\
\hline Name of Manuscript & Maqamat of Al-Hariri \\
\hline Language of Manuscript & Arabic \\
\hline Calligrapher & Yahya ibn Mahmud al-Wasiti \\
\hline Miniature (Painter) & Yahya ibn Mahmud al-Wasiti \\
\hline Production Place & Baghdad, Iraq \\
\hline Production Date & $\begin{array}{l}\text { A May 1237 A.D. / 6 Ramadan 634 } \\
\text { A.H.. }\end{array}$ \\
\hline Historical Period & Abbasid Period \\
\hline Conservation Town & Paris, France \\
\hline Conservation Place & Bibliothèque Nationale de France \\
\hline Inventory Number & MS. arabe 5847 (Schefer Hariri) \\
\hline
\end{tabular}

\section{References:}

-- إبراهيم محد إبراهيم العسال، المرأة في تصاوير المخطوطات الإسلامية، مخطوط رسالة ماجستير غيرة

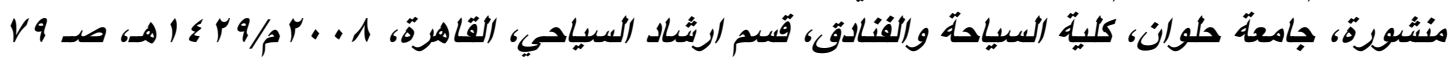
11

- Ibrahim Muhammad Ibrahim Al-Assal, Women in the Illustrations of Islamic Manuscripts, manuscript of an unpublished master's thesis, Helwan University, Faculty of Tourism and Hotels, Department of Tourist Guidance, Cairo, 2008AD/1429AH, pp. 79, 80, 81.

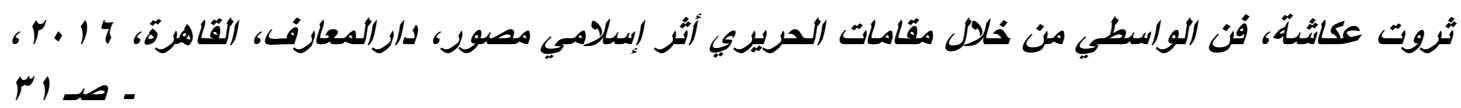

- Tharwat Okasha, Al-Wasiti Art through Maqamat Al-Hariri, an Islamic Illustrated Antiquity, Dar Al-Maarif, Cairo, 2016, p. 31.

\section{Description:}

This miniature represents a woman wearing a broad dress which covers all her body and appears on it the humerus bar. Also, her head is covering by a black yashmak that 
coats both the head and two shoulders, and dangles a part of it on the chest and the back. The woman is represented by two beautiful eyes with expressive looks directed to Abu Zayd, to the left of the painting a candlestick. This candlestick consists of an upper disk. Below the disk there is a long neck interrupted by two metal rings at the beginning and end of the neck, and the base rests on three legs.

\begin{tabular}{|l|l|}
\hline Plate No. & $(11)$ \\
\hline Miniature Name & The hour of childbirth of a woman \\
\hline Name of Manuscript & Maqamat of Al-Hariri \\
\hline Language of Manuscript & Arabic \\
\hline Miniature & Yahya ibn Mahmud al-Wasiti \\
\hline Production Place & Baghdad, Iraq \\
\hline Production Date & 3 May 1237 A.D. / 6 Ramadan 634 A.H.. \\
\hline Century & $\begin{array}{l}\text { The 13th Century A.D. / the 7th Century } \\
\text { A.H. }\end{array}$ \\
\hline Historical Period & Abbasid Period \\
\hline Conservation Town & Paris, France \\
\hline Conservation Place & Bibliothèque Nationale de France \\
\hline
\end{tabular}

\section{References:}

إبراهيم محد إبراهيم العسال، المرأة في تصاوير الدخطوطات الإسلامية، مخطوط رسالة ماجستبر غبير

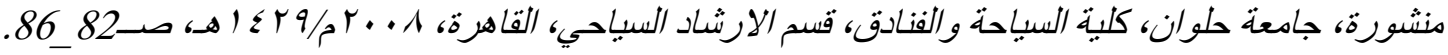

-Ettinghausen (R.) ‘ Arab Painting, Geneva: Skira, 1962, pp. 120-123.

- Grabar (O.), The Illustrations of the Maqamat, Chicago, University of Chicago Press, 1984, pp. 87- 89.

\section{Description:}

The miniature represents the difficult hour of birth for the lady of the palace and the wife of the king, where we see in the miniature six women each performing a different job to help the lady during childbirth, to the right side of the lady of the palace wearing a long brown dress, long white trousers and a blue cover that covered 
her head completely and showed off some of her hair underneath, holding Incense burner (2).

\begin{tabular}{|l|l|}
\hline Plate No. & $(12)$ \\
\hline Miniature Name & $\begin{array}{l}\text { A miniature represents a sitting queen } \\
\text { in the center and surrounding by a } \\
\text { group of the human feminine figures. }\end{array}$ \\
\hline Name of Manuscript & $\begin{array}{l}\text { The Kitab al-diryaq (The Book of the } \\
\text { Theriac, often called The Book of } \\
\text { Antidotes) of Pseudo-Galen }\end{array}$ \\
\hline Language of Manuscript & Arabic \\
\hline Miniature & Muhammad Abu al-Fath Abd alWahid \\
\hline Production Place & Probably northern Iraq \\
\hline Croduction Date & $\begin{array}{l}\text { December 1198 - January 1199 A.D. } \\
\text { /Rabi al-Awwal } 1595 \text { A.H. }\end{array}$ \\
\hline Conservation Place & Paris, France \\
\hline Inventory Number & Bibliothèque Nationale de France \\
\hline
\end{tabular}

\section{References:}

- Ettinghausen (R.), Arab Painting, Op. cit., p.92

\section{Description:}

This miniature depicting a woman in the center of the miniature is surrounded by two on the left and right side within a circular frame wearing an ornament around the good, surrounded by four women. It is notable that the women in the manuscript wear decorated and trimmed clothes and each wears an ornament around their neck.

\footnotetext{
(3) د. محمد عبدالعزبيز عمرو اللباس و الزينة في الثربعة الإسلامية،الطبعة الثانبة مؤسسة الرسالة دار

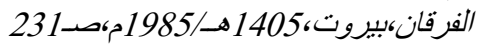




\begin{tabular}{|l|l|}
\hline Plate No. & $(13)$ \\
\hline Miniature Name & $\begin{array}{l}\text { A miniature represents a sitting queen } \\
\text { in the centre and surrounding by a } \\
\text { group of the human feminine figures }\end{array}$ \\
\hline Name of Manuscript & $\begin{array}{l}\text { The Kitab al-diryaq (The Book of the } \\
\text { Theriac, often called The Book of } \\
\text { Antidotes) of Pseudo-Galen }\end{array}$ \\
\hline Language of Manuscript & Arabic \\
\hline Miniature & Muhammad Abu al-Fath Abd alWahid \\
\hline Production Place & Probably northern Iraq \\
\hline Production Date & $\begin{array}{l}\text { December 1198 - January 1199 A.D. } \\
\text { /Rabi al-Awwal 1 595 A.H. }\end{array}$ \\
\hline Historical Period & Abbasid Period \\
\hline Conservation Place & Bibliothèque Nationale de France \\
\hline
\end{tabular}

\section{References:}

- Ettinghausen (R.), Arab Painting, Op. cit., p.92

\section{Description:}

In the center of the miniature, a seated human feminine figure enclosed by two dragons, their two tails in the bottom and their two heads in the top, and with accompany of an attendant on either side in the shape of a women. She is depicted seating as a queen on her throne in the position of the squatting, wearing a long and tight green garb with a golden stripe in its edge, bands in two sleeves and armbands. and each wears an ornament around their neck. 


\begin{tabular}{|l|l|}
\hline Plate No. & $(14)$ \\
\hline Miniature Name & A miniature shows an elegant woman \\
\hline Name of Manuscript & Maqamat of Al-Hariri \\
\hline Language of Manuscript & Arabic \\
\hline Miniature (Painter) & Unknown \\
\hline Production Place & Baghdad , Iraq \\
\hline Production Date & $1225-1235$ A.D. / 634-644 A.H. \\
\hline Historical Period & Abbasid Period \\
\hline Conservation Place & Bibliothèque Nationale de France \\
\hline Dimensions & 32 x 21.5 cm. \\
\hline Inventory Number & Ms arabe 3929 \\
\hline
\end{tabular}

\section{References :-}

- Grabar (O.), The Illustrations of the Maqamat, Op. Cit., pp. 57-59.

\section{Description:}

This miniature represents a beautiful woman wearing two bracelets around her wrists, and it seems that they were made of gold, they take the circular shape in their design.

\section{Analytical study:}

The applied artifacts in all their forms were the most prominent of manuscript paintings, and the artist's use of these objects was more than meaningful: the first was to indicate where the events of miniature took place. The second meaningful: referring to the function of the masterpiece. The third meaningful: the decorative aspect, as it was an urgent desire among the artists of the Islamic era. The decorative aspect was one of the first concerns of the Muslim artist.

The ewer ${ }^{(3)}$ is one of the most prominent metal artifacts that were used during the various Islamic eras. The ewers are considered one of the most important and most used kitchen tools on dining tables. They were used to pour water for the purposes of washing hands and also for ablution, as they were among the gifts offered to sultans 
and princes, and some ewers were only for decorative purposes (3)

The shapes of the ewers varied, and this diversity, in turn, was reflected in the depictions of the manuscripts of the Arabic school. These depictions provided us with multiple shapes of the ewer that differed from one illustration to another, in the form of the whole ewer or in some of its parts, such as the body, the base, the neck, the hand, or even the spout. More sophisticated in its form than those that appeared in the depictions of previous manuscripts.

Basins (4) are a vessel of great size that continued to be manufactured throughout Islamic times: in general form, they are a rect-flanked vessel with an outward flank, sometimes with a crooked shape; they are used either as hand-washing or as ablutions, as well as to wash fabrics and carry food and beverages in festivities, but have also acquired a religious status, such as the ruthless baptism of St. Louis, shown in the Louvre Museum in Paris, in addition to their function as a masterpiece. ${ }^{(5)}$.

Candlestick is one of the types of metal artifacts and was often made of copper enough silver or gold, and the artists continued to lead the art of antiques and metal works in Egypt, and the body of traditional candlesticks with cone hull, short neck and hanger in addition to candlesticks with a long neck with spherical rings similar to minarets and found another pattern in which the base looks like a triple pyramid connected to three legs resembling claws and above its body or a graceful column interspersed with a set of spherical rings and ends from the top with a disc that is decorated with some inscriptions ${ }^{(6)}$.

The incense burner is a device in which a stick is burned to sustain, moisten and flow with steam (also called a combustor), and incense is the input that comes from the burning of some Indian cuds. The incense burner was used in the Islamic eras of Egypt and had a great importance due to its different objectives. Three important aspects of the use of the incense burner were indicated: the religious, social, and economic aspects. It was used for fumigating religious places in the Mamluk era, such as schools and mosques, and the name of the person who assumed this function was (incense man) and it continued This tradition until the Ottoman era (7)

(2) Nabil Ali Youssef, Encyclopedia of Islamic Metal Artifacts, p. 253.

(1) In the Mamluk era, the common people predominated in the use of the term (Al-Tasht) in their lexicon, and this term is still used until the present time. 
The study showed that the Arabic miniatures had Byzantine influences such as: clothes' folds and elements of architecture, the high throne with a curtain at the back, , is considered from a Byzantine origin, and halos which appeared around women's heads(pl.14).

The study concluded that the Arabic miniatures had Sasanian influences such as: the headband.

Some miniatures show floral decorations in its background (pl.8) which appeared two trees decorated the right and left side of the miniature form the background. The garment of Irakht(pl.2) is decorated with floral decorations that are interwoven plant branches, the curtain (pl.10) is also decorated with floral decoration. Also, some geometrical decorations appeared in the bands of clothes of Abu Zayd and Al Hairith (pl.6), the ewers were also decorated with geometrical decorations.

The miniature (pl.8) shows the participation of the women in the helping of the men during preparing an antidote. This refers to that Arabic women had a great role besides men in the renaissance and development of the Islamic civilization and women are always men's partners inside the society.

The paintings of the study included different themes such as: the daily life, which illustrated and gave a good idea about the life in the Islamic community in general.

\section{CONCLUSION:}

The forms of metal artifacts that appeared in the |paintings of the manuscripts of the Arabic school varied and this appeared through the collection of ewers drawn in the miniatures of manuscripts attributed to the Arabic School can be said that there is a similarity in drawing the ewer in general, i.e., the obvious similarity here is the general form of the ewer such as drawing the base, body or neck and the hand of the ewer.

The difference was in the form of a tap that varied more in the images of manuscripts, but the artist is calculated to be able to draw various forms of pitchers, unlike the pitchers that reached us, which were all the same, are one version where there's no difference.

The study concluded that the forms of the basins differed in the illustrations of the manuscripts due to the nature of their use within the image, and according to what was stated in the text of the manuscript, but they were completely identical in their shapes, technique of manufacture and methods of decoration. The study revealed that candlestick in this way is a completely realistic painting of the candlestick shapes that 
were made in Iraq. It is certain that what was made in Egypt or Syria is similar to this shape, even if it is few. Despite the different shapes of incense burners, the method of their manufacture is almost the same, as it usually consists of a cylindrical body loaded with legs of various shapes, and this body is.

The study concluded that woman worn jewelry through the Arabic School's paintings such as: necklaces, earrings, bracelets, anklets, and rings. Which was expressing a fertile creative imagination of the Muslim artist

The study concluded that the Arabic miniatures had Sasanian influences such as: the pleasures of the court and the headband.

The study showed that the Arabic school miniatures had Byzantine influences such as: clothes' folds and elements of architecture, the high throne with a curtain at the back, which carries a judge on it inside a court, is considered from a Byzantine origin.

The study confirmed that the Arabic woman participated men in the social life during the Abbasid period in Iraq and Mamluk era in Egypt and Syria.

\section{References:}

1. أحمد بن مصطفى الدمشقى(الباييدى)در اسة وتحقيق أحمد عبدالتواب عوض، اللطائف فى اللغة، معجم أسماء الأشياء،دار الفضيلة

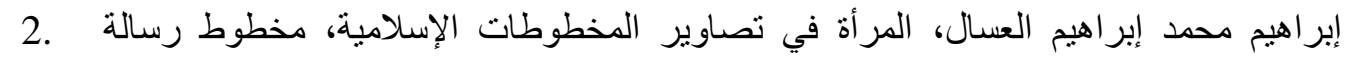

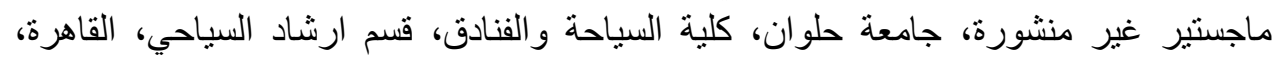

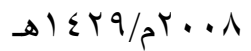

3. أبو الحمد محمود فرغلى،التصوير الإسلامى نشأته وموقف الإسلام منه،الدار المصرية

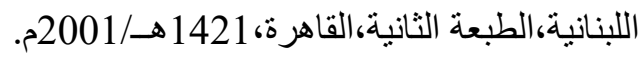

4. روت عكانشة، فن الواسطي من خلال مقامات الحريري أثر إسلامي مصور، دارالمعارف، القاهرة، باركعارف، 17

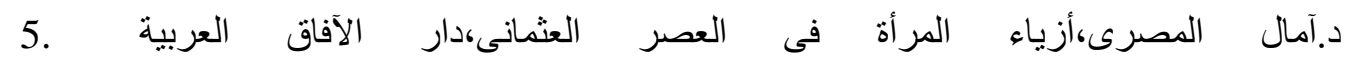
ط1، القاهرة،1419هـ/1999م.

6. .ثروت عكاثنة،فن الواسطى من خلال مقامات الحريري أثر إسلامى مصور ،الطبعة الأولى ،دار،

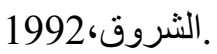

7.حسن البانشاكوسو عة العمارة و الآثار و الفنون الإسلامية،المجلد الثانى،القاهرة،1999م. 
8.زكى محمد حسن،فنون الإسلام،مكتبة النهضة المصرية،القاهرة،1948. .

9. دممد عبدالعزيز عمرو ،اللباس و الزينة فى الثريعة الإسلامية،الطبعة الثانية،مؤسسة الرسالة،دار،

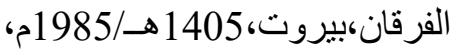

10. د.نبيل على يوسف،مصر منذ الفتح الإسلامى وحتى نهاية العصر المملوكى،ط1،الجزء الثانى،دار الفيار

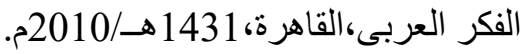

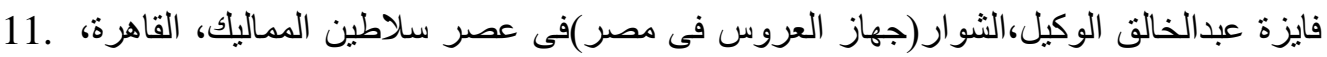

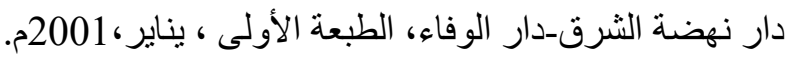

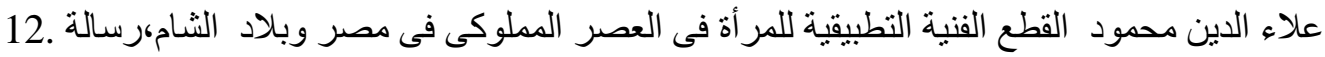

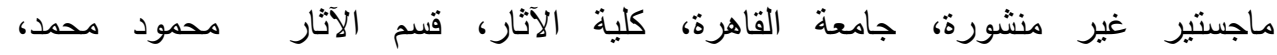
الإسلامية، القاهرة، 1432 هـ/2011م

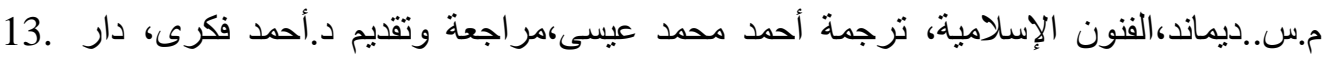

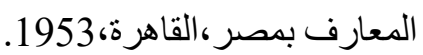

14. محمود إبراهيم حسنالمدخل فى دراسة التصوير الإسلامى ومدارسه، دار الثقافة

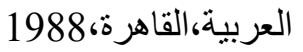

\section{Manuscripts:}

The Manuscript of Maqamat of Al-Hariri in Bibliothèque Nationale de France, Paris. Arabe. 5847.http://gallica.bnf.fr/ark:/12148/btv1b8422965p

The Manuscript of Maqamat of Al-Hariri (al-Wasiti) in Bibliothèque Nationale de France, Paris. Arabe. 5847..http://gallica.bnf.fr/ark:/12148/btv1b8422965p

The Manuscript of Maqamat of Al-Hariri in Bibliothèque Nationale de France, Paris. Arabe. 3929. http://gallica.bnf.fr/ark:/12148/btv1b8422967h

- The Manuscript of Kalila and Dimna in Bibliothèque Nationale de France, Paris. Arabe. 3465. http://gallica.bnf.fr/ark:/12148/btv1b84229611.r

\section{Foreign References:}

Atil(E.), Renaissance of Islam (Art of the Mamluk),Washington D.C.,1981.

Dimand (M. S.), A Handbook of Muhammadan Art, 2nd edition, New York, 1947.

Ettinghausen (R.), Arab Painting,Geneva,:Skira,1962.

Florence (E. D.), Mesopotamian Manuscripts of Dioscorides, The Metropolitan Museum of Art Bulletin, New Series, Vol. 8, No. 9 (May, 1950).

Grabar (O.), The Illustrations of the Maqamat,Chicago,University of Chicago press, 1984 .

Halil (T.), Dioscorides' Materia Medica Manuscripts in Turkey, No date. 
Hattstein(M.) and Delius(P.),Islam(Art and Architecture)

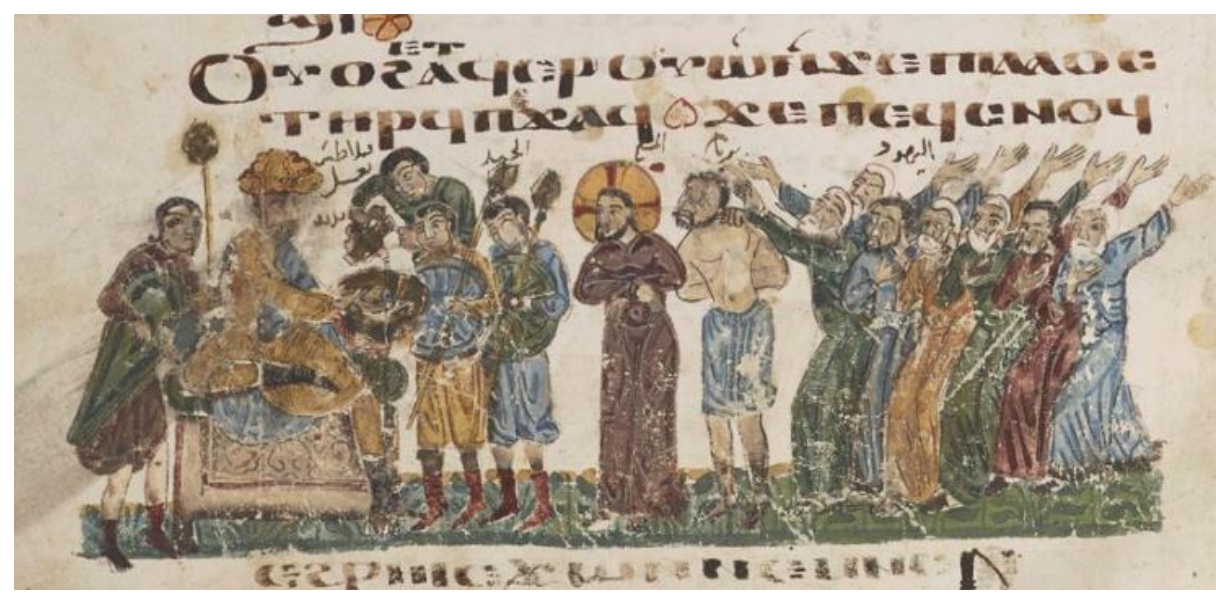

Pl.1 A miniature represents crowds of Jews gathered for asking their ruler, Pilate, to put Jesus on trial, Egypt,576 A.H./1180 A.D.,The Manuscript of Al Arba Bashair, ,preserved in Bibliothèque Nationale de France.

أبو الحمد محمود فرغلى،/التصوير الإسلامى نشأته وموقف الإسلام منه،لوحة 23،صـ415.

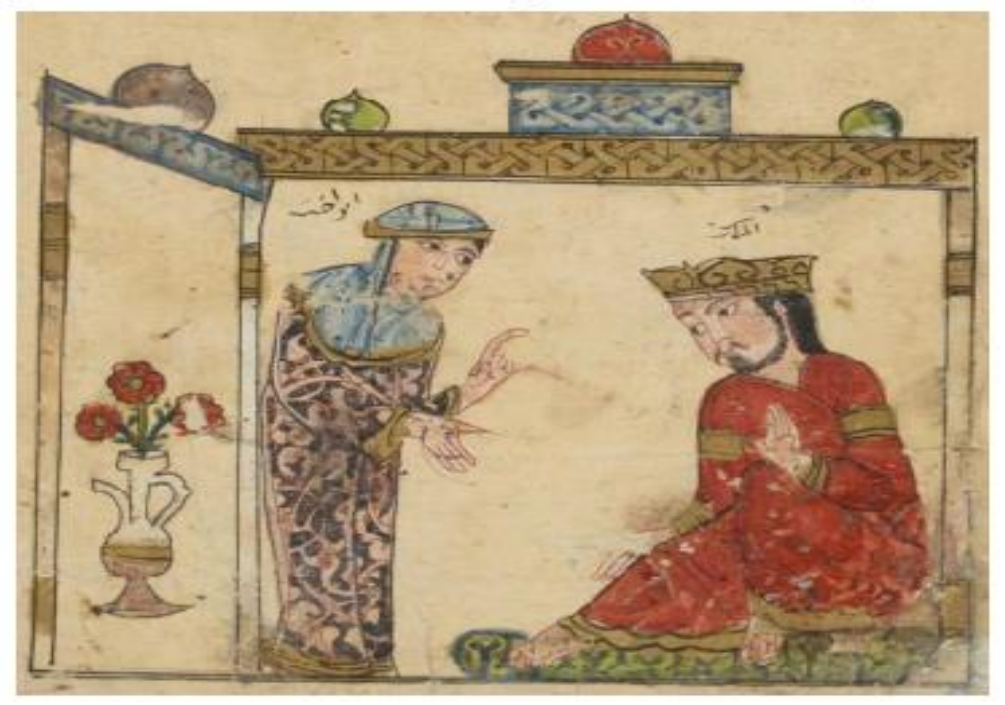

P1.2 A miniature represents a sitting king on a throne and in front of him his wife Irakht on the left side,Syria,1200_1220A.D./597_617A.H.(13th centuryA.D./7th century A.H.),Pairs, Bibliothèque Nationale de France ,Ms.arabe 3465 ,fol.132v(28x20,5cm)(After The Manuscript of Kalila and Dimna in Bibliothèque Nationale Bibliothèque de France)

.http://gallica.bnf.fr/ark:/12148/btv1b84229611.r 


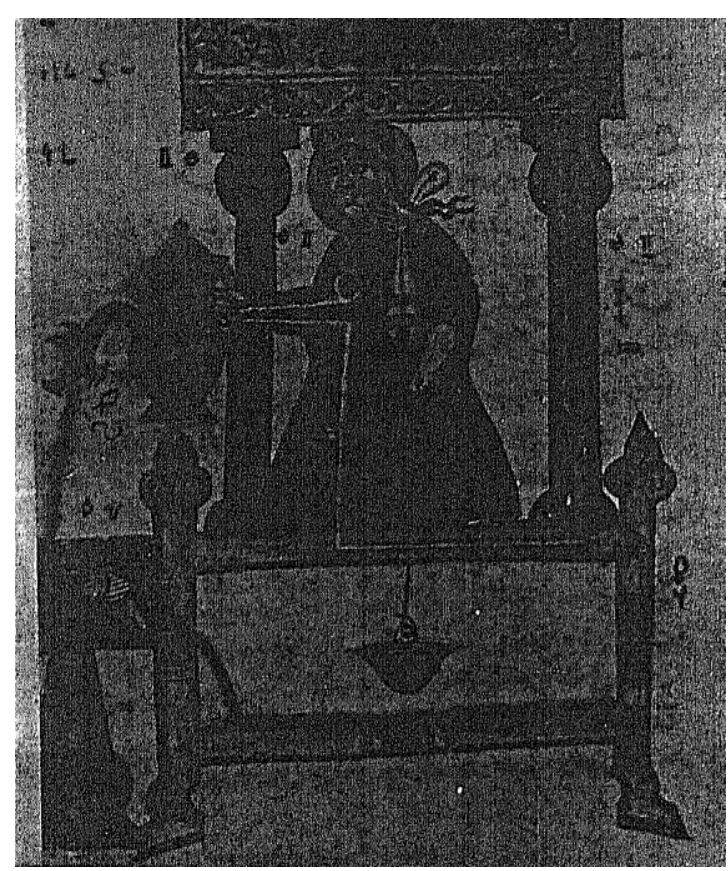

P1.3 A miniature represents group of applied arts such as ewer and bast 715 A.H./1365 A.D.,The manuscript of Kitab al-jami bayn al-ilm wa lamal al-nafi fi sina'at al-hiyal, preserved in the Freer Museum of Art in Washington.

Atil(E.), Renaissance of Islam (Art of the Mamluk),Washington D.C., 1981.

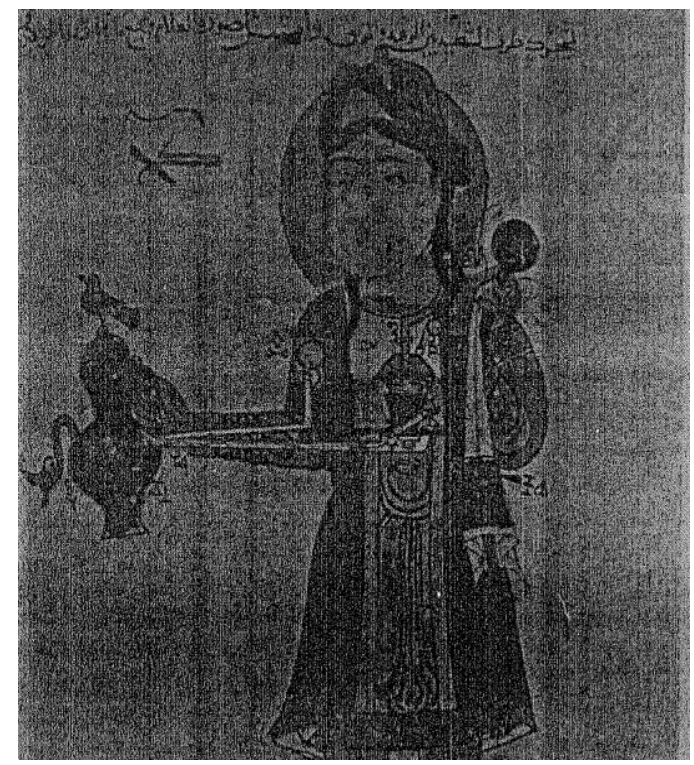

P1.4 A miniature represents a shape of ewer, 715 A.H./1365 A.D.,The manuscript of Kitab al-jami bayn al-ilm wa lamal al-nafi fi sina'at al-hiyal, preserved in the Freer Museum of Art.

Hattstein(M.) and Delius(P.),Islam(Art and Architecture),2000,p.125. 


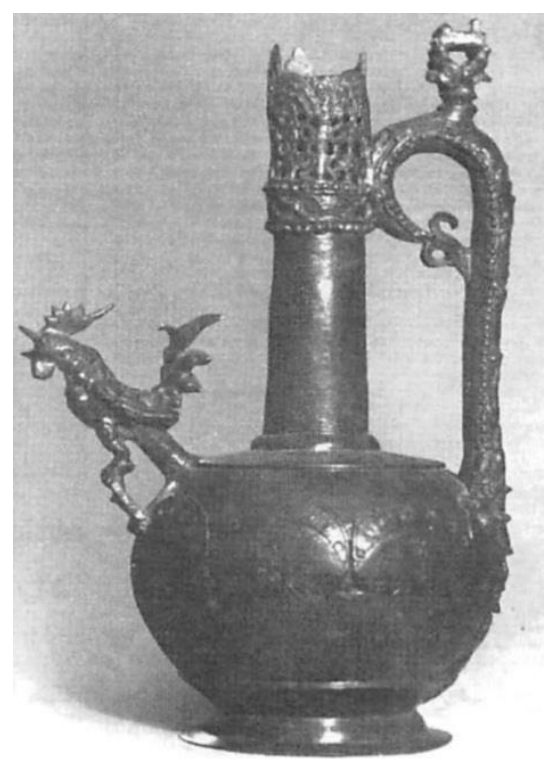

P1.5 Ewer of Marwan bin Muhammad, It was made of bronze and was found in the village of Abu Sir. Al-Malaq in Fayoum, It is preserved in the Museum of Islamic Art in Cairo.

\section{د بنبيل على بيوسف،وسوعة/لتحف الدعدنية الإسلامبة(الجزءالثانى)،دار الفكر العربى1431هـ/2010م،صـ25.}

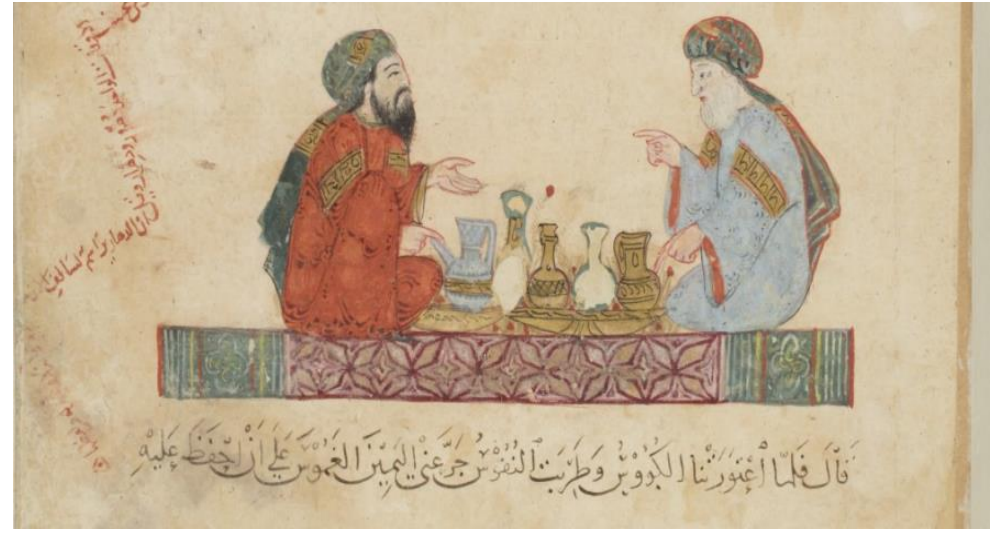

Pl.6Two men sit in drink session and in front of them two ewers,1237A.D./634A.H.(13th Century A.D./7th Century A.H) copied and illustrated by al-Wasiti,Paris, Bibliotheque Nationale de France,Ms.arabe 5847 ,fol.13v(37x28cm)(After the Manuscript of Maqamat of al-Hariri in , Bibliotheque Nationale de France).

http://gallica.bnf.fr/ark:/12148/btv1b8422965p 


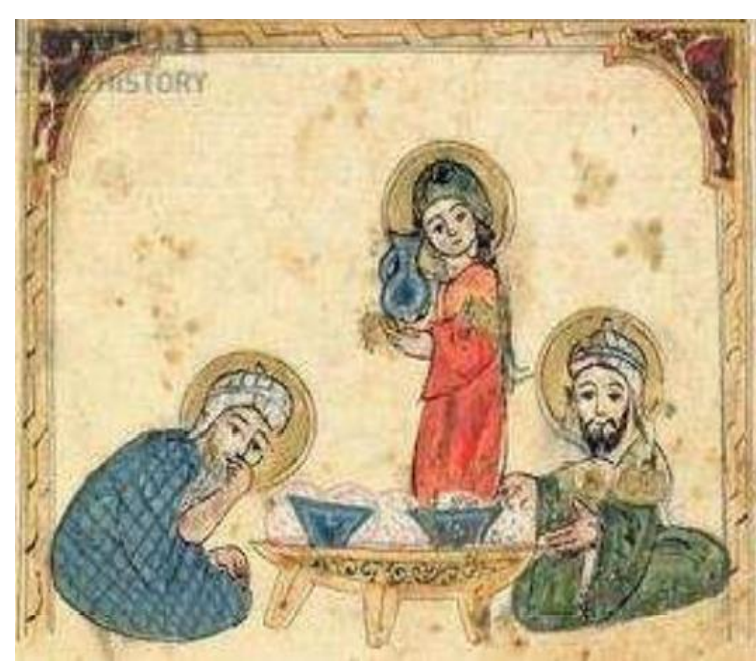

PL.7.A miniature represents a young girl as aservant bringing food to Abu Zayed and al Harith (The 15th Maqamah),Mousl,Iraq,1256a.d./645a.h.(13th century A.D./7th century A.H.),London,Britich Library,Ms.Or.1200 fol.40v(page size $24.5 \times 17 \mathrm{~cm}$, with restoration, Originally 24,5x15,5cm)(After Grabar(o).the illustrations of the Maqamat Chicago:press, 1984,pp.13,52,53,54)

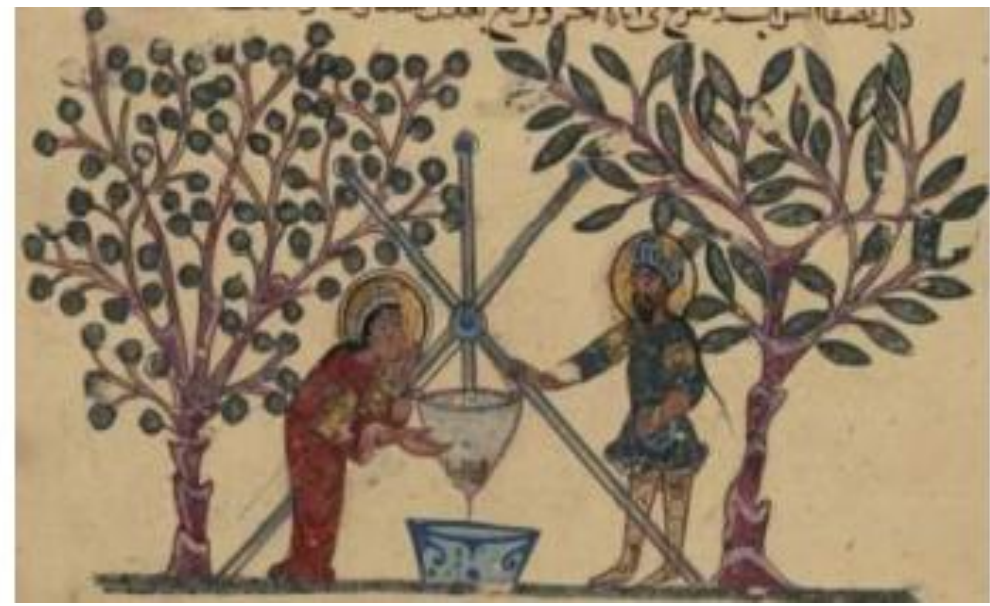

PL.8. A woman helps a pharmacist during preparing the medicine,Baghdad,Iraq, 1224 A.D./621A.H.,(13th Century/7th A.H.),New Yourk,Metropolitan,Museum of Art,W.675,page size33,5x24.9cm. Manuscript of Dioscoridess Materia Medica. 


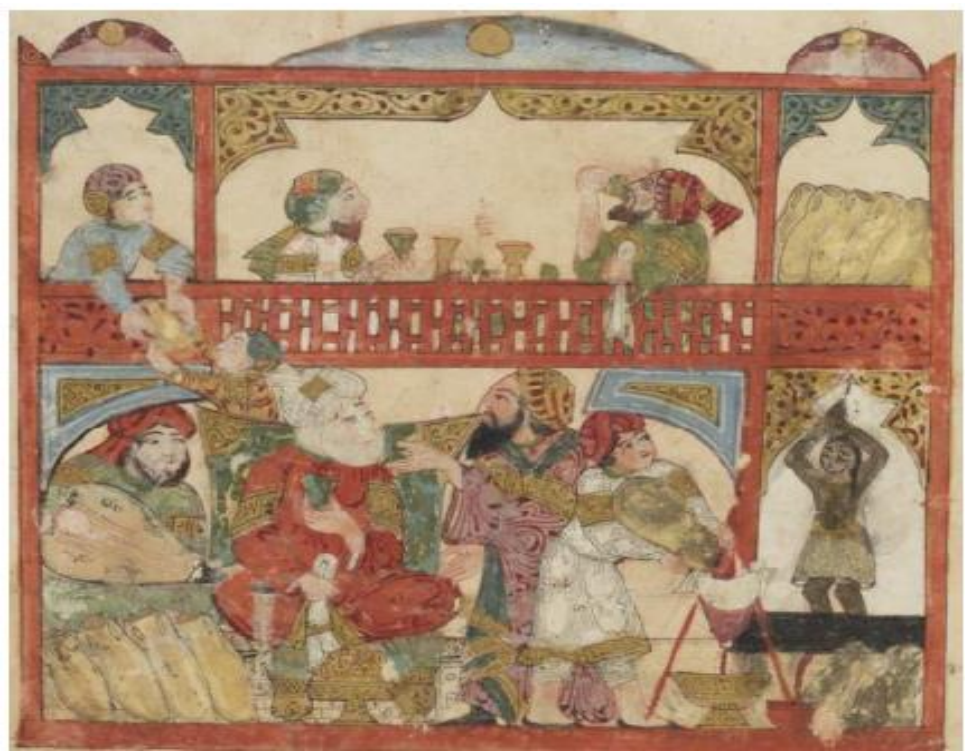

Pl. 9.Abu Zayed and al-Hairth during a meeting of glee inside a tavern in the presence of men and a dancer girl (The 12 th Maqamah),1237A.D./634A.H. .,(13th Century/7th A.H.), ) copied and illustrated by al-Wasiti,Paris, Bibliotheque Nationale de France,Ms.arabe 5847,fol.13v(37x28cm)(After the Manuscript of Maqamat of alHariri in, Bibliotheque Nationale de France).

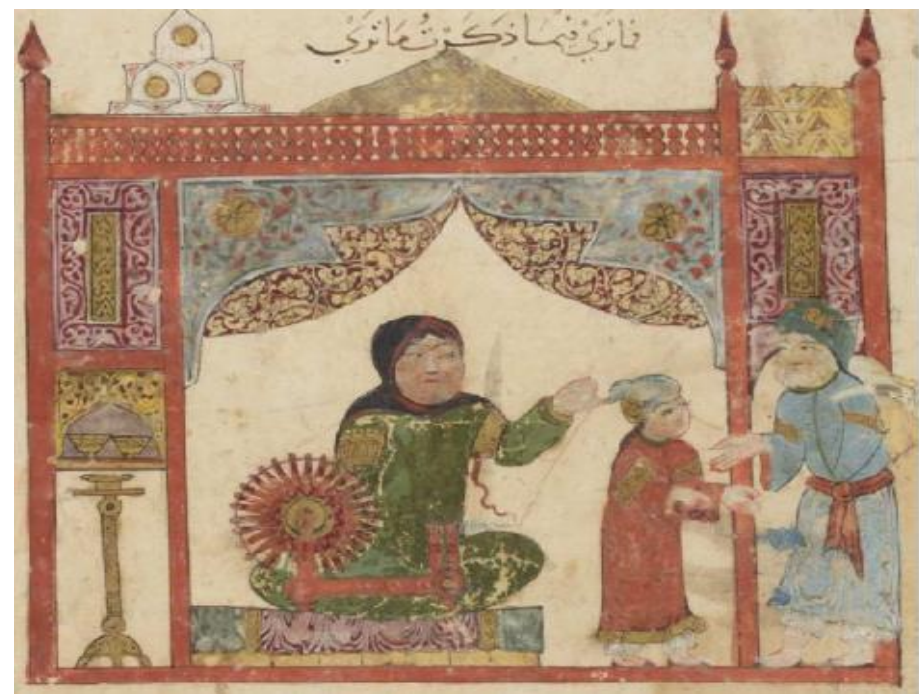

PL. 10.A woman sits in front of a spinning wheel,(The 5th Maqamah), 1237A.D./634A.H. .,(13th Century/7th A.H.), ) copied and illustrated by alWasiti,Paris, Bibliotheque Nationale de France,Ms.arabe 5847 ,fol.139v(37x28cm)(After the Manuscript of Maqamat of al-Hariri in , Bibliotheque Nationale de France). 


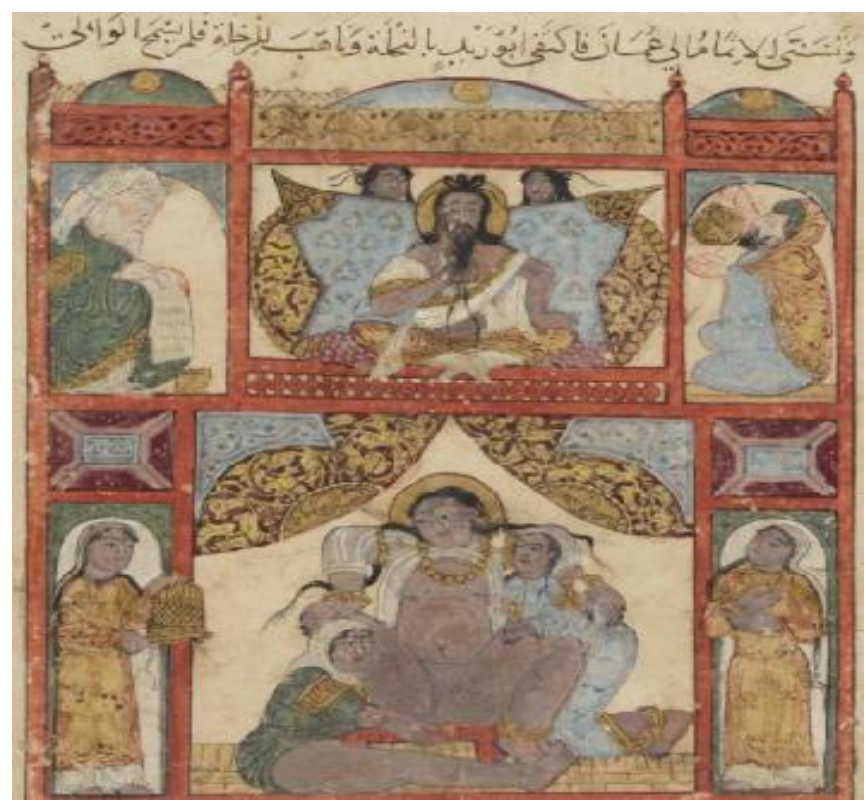

PL.11.The hour of childbirth of a woman, (The 39th Maqamah), 1237A.D./634A.H. .,(13th Century/7th A.H.), ) copied and illustrated by al-Wasiti,Paris, Bibliotheque Nationale de France,Ms.arabe 5847,fol.139v(37x28cm)(After the Manuscript of Maqamat of al-Hariri in, Bibliotheque Nationale de France).

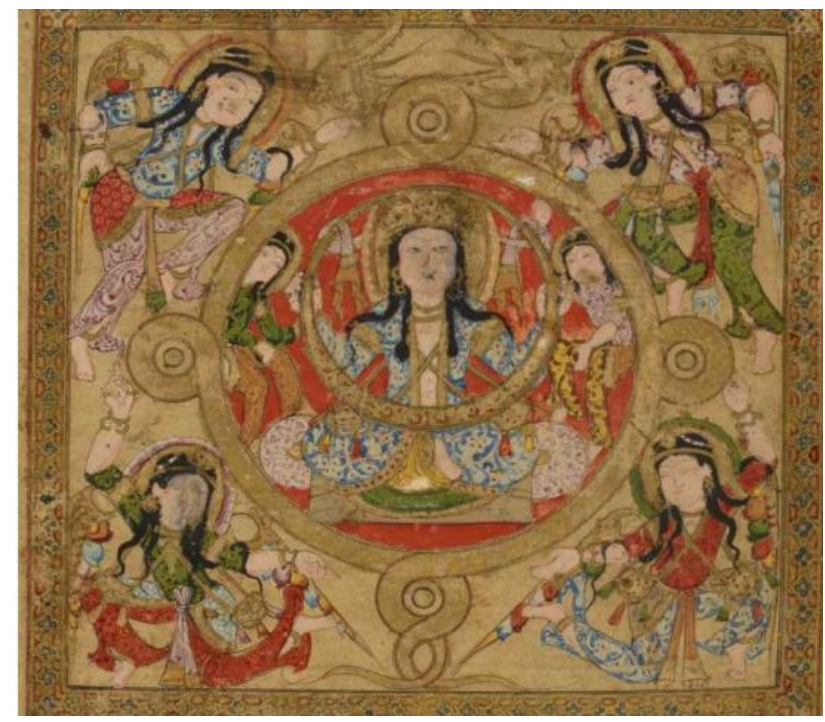

PL.12.A miniature represents a sitting queen in the center and surrounding by a group of the winged figures,propably northern Iraq,December 1198-January 1199A.D./Rabi Al-Awwal | 595 A.H.(12th Century A.D./6th Century A.H.),pairs, Bibliotheque Nationale de France,Ms arabe2964,Old page37(36,5×27,5 cm)(After The Manuscript of The book of Antidotes(Kitab ad-Diryaq) in, Bibliotheque Nationale de France).

https://gallica.bnf.fr/ark:/12148/btv1b8422960m.r 


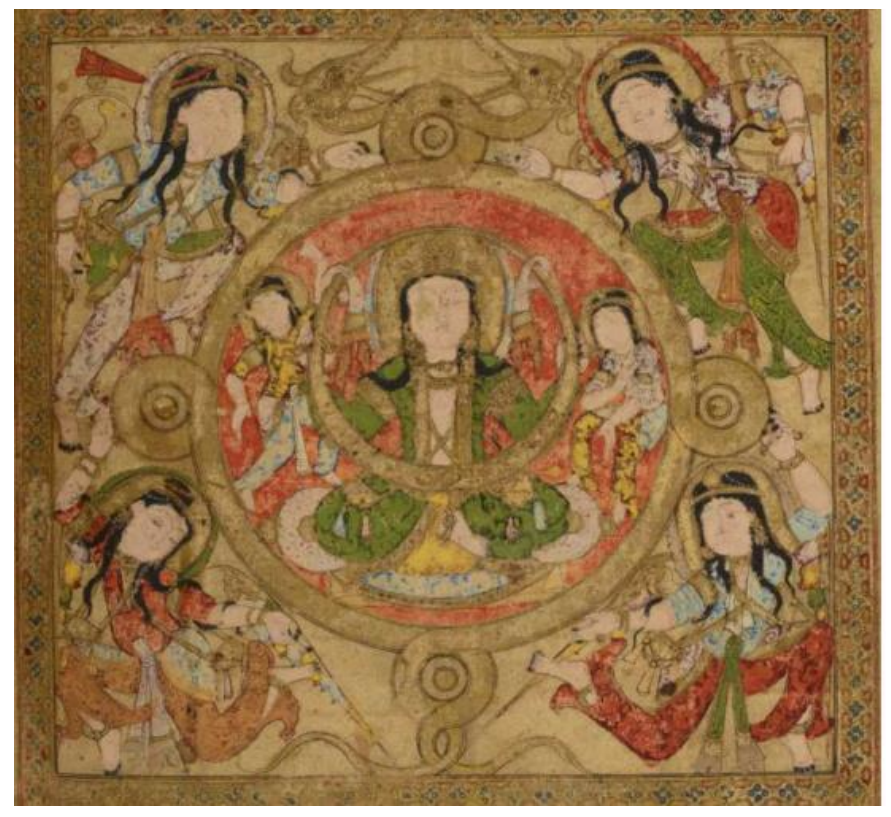

Bibliotheque

https://gallica.bnf.fr/ark:/12148/btv1b8422960m.r

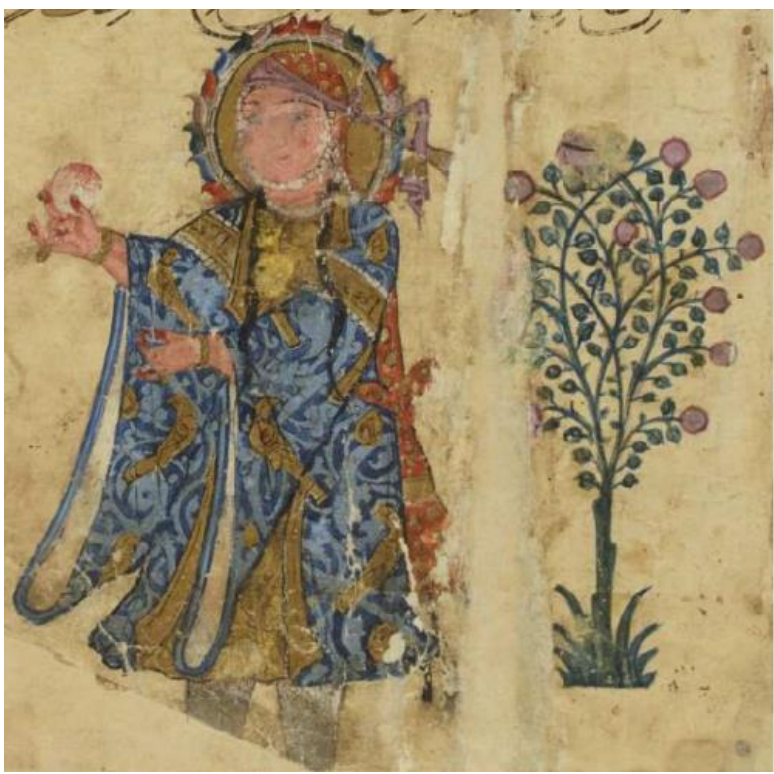

PL.13.A miniature represents a sitting queen in the center and surrounding by a group of the human feminine figures,propably northern Iraq,December 1198-January 1199A.D./Rabi Al-Awwal | 595 A.H.(12th Century A.D./6th Century A.H.),pairs, Bibliotheque Nationale de France,Ms arabe2964,Old page $37(36,5 \times 27,5 \quad \mathrm{~cm})($ After The Manuscript of The book of Antidotes(Kitab ad-Diryaq) in, de France).

PL.14.A miniature shows an elegant woman(The 18th Maqamah),12251235A.D./634-644A.H.(13th CenturyA.D./7th CenturyA.H.), pairs, Bibliotheque Nationale de France,Ms arabe3929FOL.151R $(32 \times 21,5 \mathrm{~cm}))($ After the Manuscript of Maqamat of al-Hariri in , Bibliotheque Nationale de France). http://gallica.bnf.fr/ark:/12148/btv1b8422962f 